\title{
Perbedaan Kasus Covid-19 pada Masa Lockdown dan New Normal di Indonesia
}

\author{
Nugroho Susanto ${ }^{1}$
}

${ }^{1}$ Fakultas Ilmu Kesehatan, Universitas Respati Yogyakarta

nugroho_susanto@respati.ac.id ${ }^{1}$

\author{
Diajukan 2 Februari 2021 Diperbaiki 11 Agutus 2021 Diterima 29 Agustus 2021

\section{ABSTRAK}

Latar Belakang: Pandemi COVID-19 berdampak pada peningkatan angka kesakitan dan kematian di sejumlah negara. Kasus terkonfirmasi COVID-19 yang tercatat 414.179 dengan 18.440 angka kematian (CFR 4,4\%) dilaporkan di 192 negara. Adanya penerapan kebijakan lockdown pada Maret-Mei 2020 dan new normal di Juni 2020 berdampak pada perbedaan kasus di kedua periode tersebut.

Tujuan: Mengetahui perbedaan kasus terkonfirmasi, angka kematian, dan case fatality rate (CFR) COVID-19 antara masa lockdown dan new normal di Indonesia.

Metode: Penelitian kualitatif dengan pendekatan cross-sectional disertai telaah dokumen online. Penelitian ini mengidentifikasi kasus COVID-19 selama 156 hari yang dilaporkan oleh Kementerian Kesehatan RI melalui laman https://covid19.kemkes.go.id/. Pengumpulan data dilakukan dari Maret-Agustus 2020. Analisis data menggunakan uji independent $t$ test dengan confidence interval $95 \%$ ( $\alpha$ $=0,05$ )

Hasil: Rerata kasus terkonfirmasi dan kematian akibat COVID-19 lebih tinggi pada saat new normal dibanding saat lockdown, yaitu $338,6 \pm 213,1 ; 1483,7 \pm 485,7$ dan $20,7 \pm 14,1 ; 58,9 \pm 21,9$, sedangkan case fatalty rate lebih rendah pada new normal dibanding lockdown $(0,04 \pm 0,01 ; 0,08 \pm 0,07)$. Terdapat perbedaan yang signifikan pada kasus terkonfirmasi $(p=0,000)$, angka kematian $(p=0,000)$, dan case fatalty rate COVID-19 ( $\mathrm{p}=0,000)$ antara masa pemberlakuan lockdown dan new normal.

Kesimpulan: Meskipun rerata kasus terkonfirmasi dan kematian lebih tinggi di masa new normal, rerata fatalitas kematiannya lebih rendah.

Kata Kunci: COVID-19; New normal; Lockdown; Indonesia

\section{ABSTRACT}

Background: The COVID-19 pandemic has been impacted morbidity and mortality widespread in the world.Confirmed COVID-19 cases estimated to be 414.179 with 18.440 deaths (CFR 4,4\%) were reported in 192 countries. The implemented lockdown policystarted March toMei 2020 and the new normal in June 2020 impacted the number of cases in both periods.

Objective:To determine differences in confirmed case, mortality, and fatality rate between lockdown and new normal in Indonesia.

Method: The qualitative study used a cross-sectional approach with an online document. This study identified COVID-19 cases during 156 days which were reported by the Indonesia health ministry via https:// covid19.kemkes.go.id/. Data were collected from March to August 2020. Data Analysis used independent t-test through confidence interval $95 \%(\alpha=0,05)$.

Results: The average of confirmed and mortality cases was higher in new normal than lockdown, i.e., $338,6 \pm 213,1 ; 1483,7 \pm 485,7$ and $20,7 \pm 14,1: 58,9 \pm 21,9$. However, the case fatality rate was lower in the lockdown $(0,04 \pm 0,01 ; 0,08 \pm 0,07)$. There also were significant differences in confirmed case $(p=0,000)$, death $(p=0,000)$, and fatality rate $(p=0,000)$ between in lockdown and in new normal periods.

Conclusion: Although confirmed cases and deaths werehigher in the new normal, the mortality rate waslower.

Keywords: COVID-19; New Normal; Lockdown; Indonesia 
PENDAHULUAN

Berdasarkan laporan WHO sampai 25 Maret 2020, COVID-19 telah terjadi di 192 negara dengan kasus konfirmasi COVID19 sebesar 414.179 kasus dan angka kematian sebesar 18.440 kematian (CFR 4,4\%). Pada tanggal 12 April 2020, Indonesia melaporkan kasus konfirmasi COVID-19 sebanyak 4.241 kasus. Pandemi COVID-19 menimbulkan stres dan dampak sosial baik ekonomi maupun psikologi (Kemenkes RI, 2020).

Lai et al. (2020) menunjukkan bahwa sampai tanggal 29 Februari, COVID-19 telah menyebar di 57 negara dengan estimasi kasus sebesar 80.000 kasus, dengan kematian sebesar 2.924 kematian. Bambra et al. (2020) menggambarkan pandemik berdampak terhadap ekonomi global di USA dan UK.

Coronavirus disease dilaporkan pertama kali pada 31 Desember 2019, yaitu penyakit yang sedang mewabah hampir di seluruh dunia dengan nama virus Severe Acute Respiratory Syndrome Coronavirus-2 (SARS-COV-2). Infeksi berawal di Wuhan, provinsi Hubei, Tiongkok, yang melaporkan pertama kali mengenai kasus Pneumonia yang tidak diketahui penyebabnya.

Data dari website WHO tanggal 7 Maret 2020 didapatkan kasus konfirmasi sebanyak 90.870 dengan total kematian 3.112 kasus $(3,4 \%)$ (WHO, 2020). Penelitian Goldstein and Lee (2020) menunjukkan angka kematian COVID-19 lebih tinggi dibandingkan dengan kematian penyakit lain.

Berdasarkan data per tanggal 14 Februari 2020, angka mortalitas di seluruh dunia sebesar 2,1\%, secara khusus di kota Wuhan sebesar $4,9 \%$ dan provinsi Hubei sebesar 3,1\%. Kasus di Indonesia per tanggal 14 Maret 2020 menunjukkan adanya 96 kasus yang terkonfirmasi COVID-19 dengan jumlah kematian 6 orang dan menjadi negara ke-65 yang positif terkonfirmasi COVID-19 (Depkes RI, 2020).
Penelitian sebelumnya, Ye et al. (2020), menyebutkan bahwa penularan COVID-19 terjadi melalui droplet yang mempermudah penularannya dari penderita satu ke penderita lainya. Penelitian Tay et al.(2020) menunjukkan bahwa infeksi SARS-COV-2 dan COVID19 merupakan penyakit immunophatogenesis.

Kajian kasus terkonfirmasi, kematian dan insiden kematian COVID-19 sangat penting untuk dilakukan guna untuk melihat trend, kajian faktor risiko, dan penyebab kematian. Hal tersebut dapat menjadi indikator penting dalam penanganan masalah kesehatan, khususnya COVID-19.

Penerapan lockdown dilakukan diberbagai daerah di Indonesia sebelum kebijakan new normal diberlakukan. Penerapan lockdown cenderung membatasi berbagai aktivitas masyarakat sehingga berdampak terhadap kondisi ekonomi masyarakat. Penerapan new normal ditandai dengan dibukanya fasilitas pelayanan umum di masyarakat.

Fasilitas pelayanan yang dibuka merupakan salah satu faktor terjadinya peningkatan penularan COVID-19. Adanya perubahan kebijakan dari masa lockdown ke new normal berdampak pada perbedaan angka konfirmasi kasus, angka kematian, dan insiden kematian COVID19, sehingga pendekatan dan mekanisme pencegahan dapat berbeda pada kondisi lockdown dan new normal.

Upaya memutus mata rantai penularan COVID-19 dapat dilakukan dengan berbagai cara, seperti karantina penderita, penerapan protokol kesehatan, dan jaga jarak. Undang-undang nomor 6 (enam) tahun 2018 tentang kekarantinaan kesehatan pada pasal 39 (tiga puluh sembilan) ayat 2 (dua) menyebutkan bahwa orang yang ditemukan gejala klinis sesuai dengan jenis penyakit kedaruratan kesehatan masyarakat dilakukan isolasi.

Penelitian Chu et al.(2020) menemukan bahwa physical distancing satu 
meter menurunkan penularan COVID-19. Penelitian ini bertujuan untuk mengetahui perbedaan kasus terkonfirmasi, angka kematian dan case fatality rate akibat COVID-19 antara penerapan lockdown dan new normal di Indonesia.

\section{METODE}

Rancangan penelitian kualitatif yang digunakan dalam penelitian ini adalah cross-sectional yang disertai telaah dokumen online. Populasi dalam penelitian ini adalah semua penderita COVID-19 yang telah dilaporkan oleh Departemen Kesehatan RI melalui laman website URL: https:// covid19.kemkes.go.id/ ketika mulai diberlakukan status COVID-19 sampai setelah penerapan new normal.

Sampel penelitian diambil berdasarkan kriteria inklusi yang meliputi semua penderita COVID-19 yang tercatat secara lengkap pada laman website Depkes RI (URL: https://covid19.kemkes.go.id/). Periode pengambilan sampel dilakukan dengan jumlah hari yang sama, baik pada saat lockdown maupun new normal, yaitu 78 hari.

Variabel dependen dalam penelitian ini adalah jumlah kasus terkonfirmasi, angka kematian, dan Case Fatality Rate (CFR) COVID-19. CFR dilihat dari perbandingan jumlah kematian dengan jumlah kasus terkonfirmasi, sedangkan variabel independennya adalah status pemberlakuan lockdown dan new normal.

Penentuan new normal didasarkan pada keputusan Menteri Kesehatan Nomor HK. 01.07/MENKES/328/2020 tentang panduan pencegahan dan pengendalian COVID-19 di tempat kerja, perkantoran dan industri yang diberlakukan di beberapa daerah mulai 1 Juni 2020. Penelitian dilaksanakan dengan memanfaatkan data sekunder yang telah didesiminasikan oleh Depkes RI melalui laman website URL: https:// covid19.kemkes.go.id/.

Data yang dikumpulkan mulai awal pandemi COVID-19di Indonesia, yaitudari 2 Maret 2020 sampai 31 Mei untuk periode lockdown, sedangkan untuk periode new normal dari 1 Juni sampai 2 Agustus 2020. Populasi penelitian adalah waktu pengamatan dengan satuan hari.

Pengambilan sampel hari dilakukan dengan total sampel yang memiliki catatan pelaporan lengkap (jumlah kasus terkonfirmasi dan jumlah kematian). Instrumen yang digunakan dalam penelitian adalah formulir isian data yang digunakan untuk merekap data dari website Depkes RI yang di tampilkan pada laman URL https://covid19.kemkes.go.id/.

Analisis data dilakukan dengan analisis univariat dan bivariat. Analisis univariat disajikan dalam distribusi frekuensi. Analisis bivariat digunakan dengan uji independent $t$ test dengan tingkat kepercayaan/confidence interval 95\% $(\alpha=0,05)$. Hasil penelitian telah disetujui oleh komisi etik penelitian Universitas Respati Yogyakarta dengan No. 190.3/ FIKES/PL/IX/2020 Fakultas Ilmu Kesehatan Universitas Respati Yogyakarta.

\section{HASIL DAN PEMBAHASAN}

Pengamatan dilakukan sebelum dan setelah penerapan new normal tanggal 1 Juni 2020 dengan perbandingan 78 hari saat lockdown dan 78 hari new normal. Hasil pengamatan selama 156 hari untuk melihat aspek kasus terkonfirmasi, kematian dan case fatality rate COVID-19 di Indonesia dapat terlihat pada tabel berikut.

Tabel 1. Distribusi Rerata Angka Kasus

Terkonfirmasi, Angka Kematian dan Case Fatality Rate Penderita Waktu Lockdown dan New Normal

\begin{tabular}{llrcc}
\hline \multirow{2}{*}{ No } & \multirow{2}{*}{ Variabel } & N & \multicolumn{2}{c}{ Status Pandemi } \\
\cline { 3 - 5 } & & $\begin{array}{c}\text { Lockdown } \\
\text { Mean } \pm \text { SD }\end{array}$ & $\begin{array}{c}\text { New normal } \\
\text { Mean } \pm \text { SD }\end{array}$ \\
\hline 1 & Terkonfirmasi & 78 & $338,6 \pm 213,1$ & $1483,7 \pm 485,7$ \\
2 & Kematian & 78 & $20,7 \pm 14,1$ & $58,9 \pm 21,9$ \\
3 & Case Fatality Rate & 78 & $0,08 \pm 0,07$ & $0,04 \pm 0,01$ \\
\hline
\end{tabular}

Berdasarkan Tabel 1, rerata kasus terkonfirmasi lebih tinggi pada new normal dibanding pada saat penerapan lockdown 
$(338,6 \pm 213,1 ; 1483,7 \pm 485,7)$. Data kematian COVID-19 memiliki rerata lebih tinggi pada saat penerapan new normal $(20,7 \pm 14,1 ; 58,9 \pm 21,9)$, sedangkan pada rerata case fatality rate lebih rendah pada new normal $(0,04 \pm 0,01 ; 0,08 \pm 0,07)$. Hal tersebut tersaji pada trend kasus terkonfirmasi, kasus kematian dan case fatality rate pada gambar berikut.

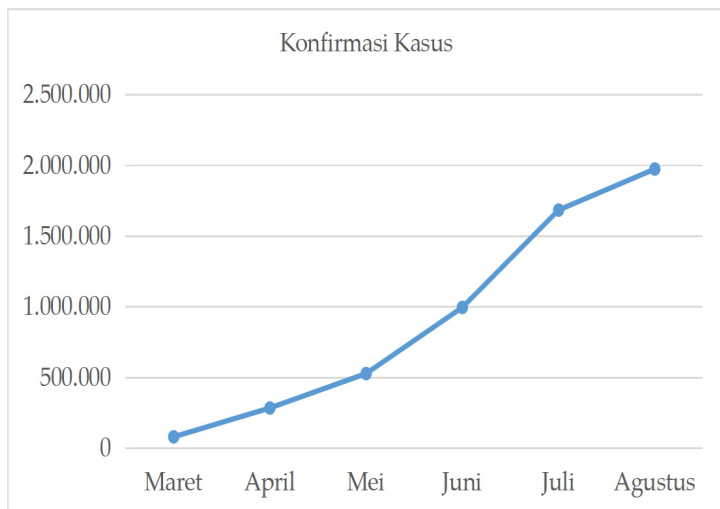

Gambar 1. Trend Kasus Terkonfirmasi Berdasarkan Bulan.

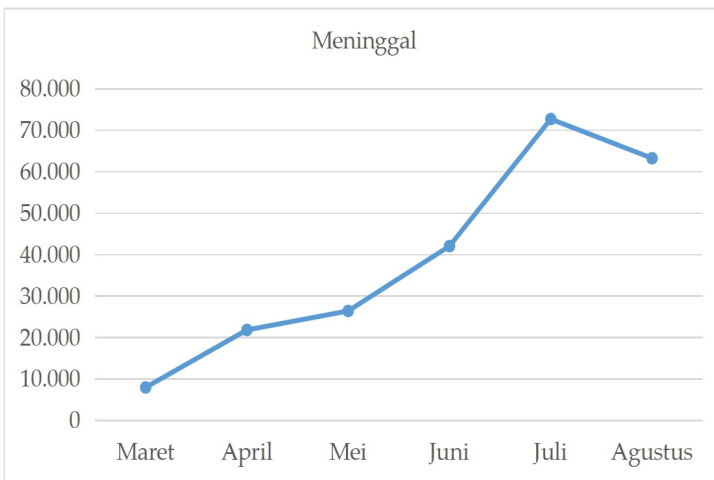

Gambar 2. Trend Jumlah Kasus Kematian Berdasarkan Bulan.

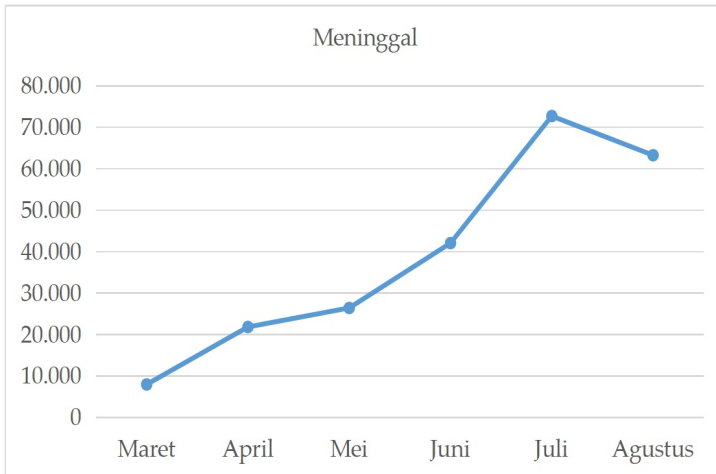

Gambar 3. Trend Case Fatality Rate Berdasarkan Bulan.

Gambar 1 menunjukkan bahwa kasus konfirmasi mengalami trend peningkatan setiap bulannya. Pada Gambar 2 angka kematian kasus COVID-19 setelah limabulan mengalami penurunan kematian kasus COVID-19, sedangkan pada Gambar 3 insiden kematian mengalami penurunan kasus COVID-19 setiap bulannya.

Hasil penelitian menunjukkan bahwa rerata angka kejadian terkonfirmasi kasus COVID-19 pada masa lockdown $338,56 \pm 213,09$, sedangkan pada masa new normal 1483,74 $\pm 485,6$. Hal ini menunjukkan bahwa angka konfirmasi kasus mengalami peningkatan. Angka konfirmasi kasus yang mengalami peningkatan dapat disebabkan proses penularan penyakit COVID-19 yang masih terus berlangsung.

Berdasarkan hasil penelitian dari berbagai negara, kejadian COVID-19 terus mengalami peningkatan. Berdasarkan laporan WHO, (2020) status COVID-19 menjadi pandemi diseluruh dunia pada 195 negara.

Berdasarkan penelitian Adnan et al. (2020), kejadian COVID-19 sudah menyerang 57 negara dengan angka kematian 2,9\%. Keadaan ini sejalan dengan situasi di Indonesia yang menunjukkan laju peningkatan kasus COVID-19 masih terus terjadi.

Pendekatan segitiga epidemiologi memungkinkan untuk menjawab pertanyaan peningkatan kasus penularan COVID-19. Peningkatan tersebut dapat dikaji berdasarkan aspek agent, host dan environment karena ketiganya berkontribusi terhadap perkembangan penyebaran kasus COVID-19.

Berdasarkan aspek agen, kemudahan penularan dari satu penderita ke penderita lain meningkat yang disebabkan karena virus tersebut dapat menular melalui droplet dan kontak. Penelitian sebelumnya yang dilakukan Ye et al. (2020) menyebutkan penularan COVID-19 melalui droplet dapat terjadi sehingga hampir semua penduduk berstatus suceptible.

Berdasarkan pendekatan aspek host, kerentanan host dapat terlihat terutama pada usia lanjut, anak-anak dan orang 
yang memiliki penyakit penyerta seperti diabetes, jantung, dan gizi buruk (Susanto, 2018). Penelitian Tay et al. (2020) menyebutkan bahwa infeksi SAR-C0v-2 merupakan penyakit immunophatogenesis. Disfungsi imunitas terjadi pada penyakit COVID-19 yang berakibat pada gangguan immunophatogenesis sehingga berdampak pada kekebalan tubuh. Upaya perbaikan imunitas menjadi hal mendasar dalam pencegahan COVID-19.

Berdasarkan aspek lingkungan, dapat dilihat dari perilaku host dalam mencegah penularan COVID-19 sehingga menyebabkan penularan masih terus berlangsung. Berdasarkan hasil review penelitian sebelumnya oleh $\mathrm{Chu}$ et al. (2020), physical distancing satu meter atau lebih menjadi kebijakan dalam menurunkan penularan penyakit COVID19.

Penerapan protokol kesehatan yang kurang baik merupakan salah satu penyebab peningkatan penularan penyakit COVID-19 di Indonesia. Protokol kesehatan yang sering tidak dipatuhi, antara lain cuci tangan, menyentuh mata, menghindari kontak, mengunakan masker, dan isolasi mandiri. Upaya memutus mata rantai penularan COVID19 menjadi faktor penentu penurunan ataupun peningkatan kasusCOVID-19.
Berdasarkan angka kematian, rerata angka kematian saat lockdown lebih rendah jika dibandingkan dengan new normal. Pada new normal, peningkatan terjadi karena penularan masih terus berlanjut, upaya penanganan dan kesadaran masyarakat dalam pencegahan penularan masih minim.

Hasil penelitian ini sejalan dengan kondisi diberbagai negara seperti di Cina. Penelitian Lai et al. (2020) menyebutkan bahwa 92,9\% kasus di Cina disertai dengan angka kematian. Laporan WHO pada Maret 2020 mencatat 16.000 kematian akibat COVID-19 dan, dari 28 negara, angka kematian menunjukkan sebesar 2,5\%. Penelitian Kumar \& Misra, (2020) di India menunjukkan bahwa sebagian besar penderita COVID-19 tidak menimbulkan gejala berkisar antara 26$76 \%$.

Upaya pencegahan kematian COVID19 menjadi upaya penting dalam menurunkan angka kematian COVID-19 melalui penatalaksanaan COVID-19 yang baik. Penatalaksanaan penderita COVID19 antara lain adalah isolasi, pengendalian infeksi, suplementasi oksigen, dan penanganan hipoksia berat. Berdasarkan hasil analisis bivariat, perbedaan antara penerapan lockdown dan new normal seperti terlihat pada Tabel 2.

Tabel 2. Perbedaan Angka Kasus Terkonfirmasi, Kematian dan Case Fatality Rate Berdasarkan Penerapan lockdowndan New Normal.

\begin{tabular}{|c|c|c|c|c|c|}
\hline \multirow[b]{2}{*}{ No } & \multirow[b]{2}{*}{ Variabel } & \multicolumn{2}{|c|}{ Status Pandemi } & \multirow[b]{2}{*}{$\mathbf{t}$} & \multirow[b]{2}{*}{$p$} \\
\hline & & $\begin{array}{l}\text { Lock down } \\
\text { Mean } \pm \text { SD }\end{array}$ & $\begin{array}{l}\text { New normal } \\
\text { Mean } \pm \text { SD }\end{array}$ & & \\
\hline 1 & Terkonfirmasi & $338,6 \pm 213,1$ & $1483,7 \pm 485,7$ & $-19,06$ & 0,000 \\
\hline & Kematian & $20,7 \pm 14,1$ & $58,9 \pm 21,9$ & $-12,96$ & 0,000 \\
\hline 3 & Case Fatality Rate & $0,08 \pm 0,07$ & $0,04 \pm 0,01$ & 4,64 & 0,000 \\
\hline
\end{tabular}

Berdasarkan Tabel 2 diketahui bahwa terdapat perbedaan signifikan antara kasus terkonfirmasi pada saat lockdown dan new normal $(p=0,000)$. Hal ini juga terjadi pada angka kematian COVID-19 dan CFR di kedua periode tersebut $(\mathrm{p}=$ $0,000)$.

Keadaan pada new normal ini dapat disebabkan berbagai aspek pelayanan yang telah dibuka kembali sehingga penularan COVID-19 tidak saja di level masyarakat melainkan pada level keluarga. Penularan pada level keluarga menjadi perhatian penting dalam penanganan COVID-19.

Penelitian Chu et al. (2020) menyebutkan bahwa jarak satu meter berisiko $\mathrm{RR}=2,02 ; 95 \% \mathrm{CI}=1,08-3,76, \mathrm{p}=$ 
0,041 untuk terinfeksi COVID-19. Pada penelitian yang sama, mengunakan masker dapat melindungi COVID-19 AOR $=0,15,95 \%$ CI= 0,07-0,34. Penelitian Feleke et al. (2021) menunjukkan bahwa pengetahuan rendah $[\mathrm{AOR}=22,73,95 \%$ CI $(10,5-49,21), \quad P=0,01]$, tinggal di pedesaan $[\mathrm{AOR}=2,08,95 \% \mathrm{CI}(1,08-4,88)$, $\mathrm{P}=0,04$ ] dan tidak memiliki televisi [AOR $=2,24,95 \%$ CI $(1,05-4,79), P=0,01]$ secara signifikan berhubungan dengan penurunan praktik protokol COVID-19.

Penelitian Chan et al. (2020) menunjukkan bahwa transmisi COVID-19 sudah menyerang tenaga kesehatan yang menangani penyakit COVID-19. Keadaan ini dapat menimbulkan klaster penularan pada keluarga tenaga medis.

Ali (2020) menyatakan bahwa pelaksanaan operasi berisiko menularkan COVID-19 (87\%) sehingga diperlukan operasi yang aman. Penularan yang terjadi pada klaster keluarga perlu mendapatkan perhatian khusus dan strategi khusus dalam pencegahannya.

Sebab lain yang memicu peningkatan kasus pada saat new normal adalah mulai dibukanya kembali berbagai fasilitas pelayanan umum di masyarakat seperti supermarket, pasar, dan layanan publik perkantoran. Kebijakan new normal meningkatkan resiko penularan COVID19 yang terjadi melalui interaksi kontak di fasilitas umum dan perkantoran.

Pencegahan penularan pada fasilitas umum dan perkantoran menjadi aspek penting dalam upaya memutus mata rantai penularan COVID-19. Upaya pencegahan dilakukan melalui karantina penderita termasuk yang memiliki kontak dengan orang tersebut, karena hal ini dapat memutus mata rantai penularan COVID-19 (Wanget al.,2020).

Upaya kebijakan pemerintah, baik pusat, daerah, maupun pada level kelurahan, yang menerapkan sistem lockdown efektif dalam menekan angka penularan COVID-19. Pemberlakuan lockdown di awal pandemi COVID-19 menyebabkan aktivitas masyarakat dibatasi di setiap daerah. Keadaan ini berefek pada rerata kasus terkonfirmasi dan kematian yang cenderung lebih rendah jika dibandingkan dengan new normal.

Meskipun demikian, penelitian Carlucci et al. (2020) memberikan kesimpulan bahwa lockdown berdampak sebagai masalah bagi masyarakat. Mereka cenderung protes terhadap kebijakan pemerintah tersebut. Kebijakan lockdown selama pandemi efektif dalam mengontrol infeksi COVID-19, tetapi disisi lain berdampak terhadap ekonomi masyarakat.

Rhyan et al. (2020) menyatakan bahwa dampak pandemi mengakibatkan pertumbuhan ekonomi mengalami resesi, khususnya dibidang kesehatan. Goldstein and Lee (2020) menyebutkan bahwa pandemi COVID-19 mengakibatkan masyarakat kehilangan pekerjaan dan terisolasi dari saudara dan sahabat karena proses lockdown yang berjalan.

Upaya kebijakan lockdown berdampak pada kondisi ekonomi, kondisi sosial, dan psikososial masyarakat, sehingga kebijakan lockdown diakhiri pada bulan Mei 2020. Kebijakan lockdown dirubah menjadi kebijakan new normal mulai 1 Juni 2020. Perubahan kebijakan new normal memerlukan pendekatan berbeda dalam upaya pencegahan penularan COVID-19.

Upaya yang efektif pada kondisi new normal adalah dengan penerapan protokol kesehatan. Pedoman pencegahan COVID19 menyebutkan upaya pencegahan penularan COVID-19 yang efektif adalah dengan mengunakan masker, pengunaan hand hygiene, dan usaha-usaha pencegahan lainnya.

\section{PENUTUP}

Terdapat perbedaan signifikan kasus terkonfirmasi, angka kematian, dan Case Fatality Rate COVID-19 antara masa penerapan lockdown dan new normal di Indonesia. Terjadi peningkatan konfirmasi 
Perbedaan Kasus Covid-19 pada Masa Lockdown dan...

kasus dan angka kematian COVID-19 pada new normal dibanding lockdown, tetapi Case Fatality Rate kematian lebih tinggi pada lockdown dibanding new normal. Berdasarkan hasil penelitian dan pembahasan disarankan untuk melakukan penelitian lebih lanjut terkait pemanfaatan pelayanan oleh masyarakat dan dampak ekonomi pada masyarakat selama pandemi COVID-19.

\section{DAFTAR PUSTAKA}

Adnan, M. et al. (2020) 'COVID-19 infection: Origin, transmission, and characteristics of human coronaviruses', Journal of Advanced Research, 24, pp. 91-98. doi: 10.1016/ j.jare.2020.03.005.

Ali, M. J. (2020) 'ORIGINAL RESEARCH A Survey on the Impact of COVID-19 on Lacrimal Surgery: The Asia-Pacific Perspective', pp. 3789-3799.

Bambra, C. et al. (2020) 'The COVID-19 pandemic and health inequalities', pp. 1-5. doi: 10.1136/jech-2020-214401.

Carlucci, L., Ambrosio, I. D. and Balsamo, M. (2020) 'Demographic and Attitudinal Factors of Adherence to Quarantine Guidelines During COVID-19: The Italian Model', 11(October), pp. 1-13. doi: 10.3389/ fpsyg.2020.559288.

Chan, J. F. et al. (2020) 'A familial cluster of pneumonia associated with the 2019 novel coronavirus indicating personto-person transmission: a study of a family cluster', The Lancet, 395(10223), pp. 514-523. doi: 10.1016/S01406736(20)30154-9.

Chu, D. K. et al. (2020) 'Articles Physical distancing, face masks, and eye protection to prevent person-toperson transmission of SARS-CoV-2 and COVID-19: a systematic review and meta-analysis', pp. 1973-1987. doi: 10.1016/S0140-6736(20)31142-9.

Depkes RI (2020) 'Analisis data covid-19 indonesia'.

Feleke, B. T., Wale, M. Z. and Yirsaw, M. T.
(2021) 'Knowledge, attitude and preventive practice towards COVID19 and associated factors among outpatient service visitors at Debre Markos compressive specialized hospital ', PLoS ONE, 16(7), pp. 1-15. doi: 10.1371/journal.pone.0251708.

Goldstein, J. R. and Lee, R. D. (2020) 'Demographic perspectives on the mortality of COVID-19 and other epidemics'. doi: 10.1073/ pnas.2006392117.

Kementerian Kesehatan Republik Indonesia (2020) 'Pedoman Pencegahan dan Pengendalian Coronavirus Disease (COVID-19)', Germas, pp. 0-115. Available at: https:// infeksiemerging.kemkes.go.id/ download/REV-

04_Pedoman_P2_COVID-

19_27_Maret2020_TTD1.pdf [Diakses 11 Juni 2021].

Kumar, A. and Misra, A. (2020) 'Since January 2020 Elsevier has created a COVID-19 resource centre with free information in English and Mandarin on the novel coronavirus COVID- 19 . The COVID-19 resource centre is hosted on Elsevier Connect, the company ' $s$ public news and information ', (January).

Lai, C. et al. (2020) 'International Journal of Antimicrobial Agents Global epidemiology of coronavirus disease 2019 ( COVID-19 ): disease incidence, daily cumulative index, mortality, and their association with country healthcare resources and economic status', International Journal of Antimicrobial Agents, 55(4), p. 105946. doi: 10.1016/j.ijantimicag.2020.105946.

Rhyan, C., Turner, A. and Miller, G. (2020) 'Tracking the U.S. health sector: the impact of the COVID - 19 pandemic', Business Economics, (0123456789). doi: 10.1057/s11369-020-00195-z.

Susanto, N. \& F. A. (2018) 'Zonasi Komplikasi Penyakit Diabetes di Wilayah Bencana', Jurnal Formil 
(Forum Ilmiah) KesMas Respati, 3(2), pp. 143-149.

Tay, M. Z. et al. (2020) 'The trinity of COVID-19: immunity, inflammation and intervention', Nature Reviews Immunology, 20(6), pp. 363-374. doi: 10.1038/s41577-020-0311-8.

Tay, M. Z. et al. (no date) 'The trinity of COVID-19: immunity, inflammation and intervention 1,2'. doi: 10.1038/ s41577-020-0311-8.

Wang, M., Liu, F. and Zheng, M. (2020) 'Air quality improvement from COVID-19 lockdown: evidence from
China', (2).

WHO (2020a) Coronavirus Disease Coronavirus Disease Coronavirus Disease Internal for SEARO Ikhtisar Kegiatan Situation World Health World Health Organization Organization.

WHO (2020b) 'Coronavirus Disease Ikhtisar Kegiatan', 19, pp. 1-13.

Ye, Q. et al. (2020) 'Epidemiological analysis of COVID - 19 and practical experience from China', J Med Virol., (March), pp. 1-15. doi: 10.1002/ jmv.25813. 